\title{
The Student Guide to
}
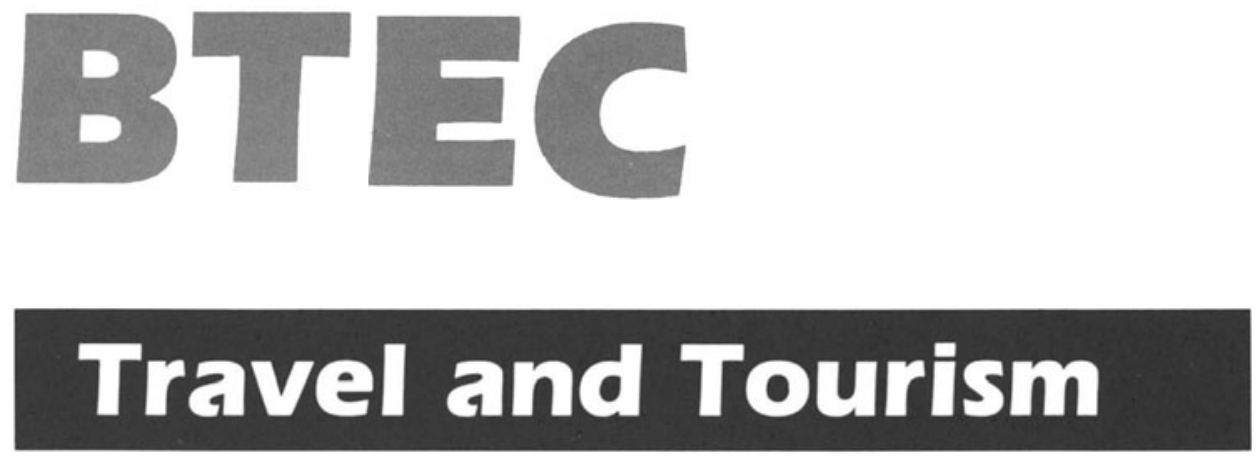

\section{Mary Allen}

North Tyneside College

Series Editor: Alan Kitson

Bolton Institute of Higher Education 
(C) Mary Allen 1991

All rights reserved. No reproduction, copy or transmission of this publication may be made without written permission.

No paragraph of this publication may be reproduced, copied or transmitted save with written permission or in accordance with the provisions of the Copyright, Designs and Patents Act 1988, or under the terms of any licence permitting limited copying issued by the Copyright Licensing Agency, 33-4 Alfred Place, London WC1E 7DP.

Any person who does any unauthorised act in relation to this publication may be liable to criminal prosecution and civil claims for damages.

First published 1991

Published by

MACMILLAN EDUCATION LTD

Houndmills, Basingstoke, Hampshire RG21 2XS

and London

Companies and representatives

throughout the world

British Library Cataloguing in Publication Data

Allen, Mary

Travel and tourism. - (The student guide to BTEC).

1. Tourism

I. Title II. Kitson, Alan III. Series 338.4791

ISBN 978-0-333-51729-1

ISBN 978-1-349-11321-7 (eBook)

DOI 10.1007/978-1-349-11321-7 


\section{Contents}

Unit 1 Introduction 1

How the course is made up 1

Range of possible career opportunities 3

'I had something rather different in mind' 4

What skills must I develop to be successful?

$\begin{array}{lll}\text { Unit } 2 \text { Learning with BTEC } & 7\end{array}$

What is a unit? $\quad 8$

Ways of acquiring knowledge and skills $\quad 9$

Unit 3 Learning in travel and tourism with BTEC 13

About BTEC and the ABTA NTB 13

The range of jobs in travel and tourism 16

What the course should help you to achieve 16

$\begin{array}{ll}\text { The design of the courses } & 17\end{array}$

How your development is assessed 18

Unit 4 How to tackle your travel and tourism assignments 29

What are assignments $\quad 29$

Types of assignments $\quad 30$

How assignments are set $\quad 38$

The Programme of Integrative Assignments $\quad 39$

Tackling assignments successfully $\quad 39$

Some help with assignment no. 1

Unit 5 How your work will be assessed 51

Assessment criteria $\quad 51$

What does assessment really mean? 52

How are assignments marked? $\quad 55$

How do we assess each other? $\quad 57$

The role of the moderator $\quad 58$

Do I have to sit exams? $\quad 60$

$\begin{array}{ll}\text { Assessment outside college } & 60\end{array}$ 
iv Contents

Unit 6 Sample assignments in travel and tourism 66

As the first year progresses $\quad 66$

A travel services/travel geography assignment 67

$\begin{array}{ll}\text { An assignment based on a residential visit } & 78\end{array}$

Unit 7 Illustrative assignments 83

An induction assignment $\quad 84$

$\begin{array}{ll}\text { A business assignment } & 87\end{array}$

An assignment for the end of the first year 90

$\begin{array}{ll}\text { Second-year assignments } & 94\end{array}$

$\begin{array}{ll}\text { Keeping up-to-date with the industry } & 99\end{array}$

$\begin{array}{ll}\text { Appendix } & 103\end{array}$

$\begin{array}{ll}\text { Organisations } & 103\end{array}$

$\begin{array}{ll}\text { Useful publications } & 104\end{array}$ 


\section{Acknowledgements}

I have received help, support and encouragement from my husband, Derek, who has himself worked in the travel industry for many years.

I am indebted to my colleagues at North Tyneside College, whose assignments I have freely plundered and who make up a superb travel and tourism teaching team. A great deal of thought, imagination and hard work over the past few years has been contributed by Judy George, Judith Jenkins, Muriel Bell, David Taylor and Peter Crane.

Mary Allen

The author and publishers wish to thank the following for the use of copyright material: Association of British Travel Agents; Bradford Enterprise Service; Brittany Ferries; British Airways; British Railways Board; Business and Technician Education Council; J. Allan Cash Ltd; Thomas Cook Group Ltd; Dail Mail; Godfrey Davies; Discovery Press; Horizon Holidays; Independent Newspapers; Intasun; London Tourist Authority; P \& O European Ferries; Redwing Holidays; Jason Scott, Wallsend; Syndication International; Alan Thomas; Thomson Holidays; Today Newspapers; Travel Bulletin; Travel News; Travel Trade Gazette.

Every effort has been made to trace copyright holders, but if any have been inadvertently overlooked the publishers will be pleased to make the necessary arrangements at the first opportunity. 